IJOTL TL, Vol. 5, No. 3, September 2020

p ISSN: 2502 2326; e ISSN: 2502 8278

Https://soloclcs.org; Email: ijolt1@gmail.com

Center of Language and Cultural Studies, Surakarta, Indonesia

Nuning. (2020). Picture Word Inductive Model to Improve the Ability

of Procedure Writing of the MTs Students.

IJOTL TL (2020), 5(3), 181 196. DOI: 10.30957/ijot1 11.v5i1.636.

\title{
Picture Word Inductive Model to Improve the Ability of the Procedure Writing of the MTs Students
}

\author{
Nuning \\ MTs Negeri 1 Jepara Indonesia \\ Email: nuning.jepara1111@gmail.com
}

\begin{abstract}
This study aims to improve the students' outcomes in learning to write English procedural texts through Picture Word Inductive Model (PWIM). The research subjects were 27 students of MTs Negeri 1 Jepara. This research was conducted in 3 cycles in which the students worked in groups of four. In first cycle the students describe a picture of a certain food or drink menu using the PWIM, while in second cycle the students explain the procedure of making food/drink recipes as in cycle 1 . In third cycle, the students ask for or provide information on food/beverage recipes using the PWIM. Data collection was carried out simultaneously with observation during the action, while the data analysis was carried out simultaneously at the time of reflection on the action. From the results of analysis/reflection it reveals whether the action will be terminated (if it has reached the target) or continues to achieve the target. The data analysis was performed using the triangulation method. The results showed that there was an increase in student learning outcomes in participating in learning English writing with the PWIM. In the original situation there were only 8 students $(22.22 \%)$ out of 27 students who could describe certain objects/people/ places. In the first cycle of action, there were 10 students $(37.04 \%)$ who could make the procedure text more correctly. In the second cycle, 17 students $(62.96 \%)$ could write procedural texts correctly. In the third cycle, there was an increase in student learning outcomes. There were 27 students $(100 \%)$ who could write the procedural text correctly.
\end{abstract}

Keywords: learning outcomes, procedure text, Picture Word Inductive Model

\section{INTRODUCTION}

Writing is one of language skills that students must learn, by which a person can convey their ideas, thoughts and feelings to others. The writing advantage compared to speaking is that students have more opportunities to compose words to convey their ideas, thoughts and feelings to others. Writing is not only composing but also arranging words, phrases or sentences. The students need to follow certain language rules to be able to produce writing that can be understood and accepted by readers (Ferrance, 2000; Hammond, 2012). 
IJOTL TL, Vol. 5, No. 3, September 2020

p ISSN: 2502 2326; e ISSN: 2502 8278

Https://soloclcs.org; Email: ijolt1@gmail.com

Center of Language and Cultural Studies, Surakarta, Indonesia

Nuning. (2020). Picture Word Inductive Model to Improve the Ability

of Procedure Writing of the MTs Students.

IJOTL TL (2020), 5(3), 181 196. DOI: 10.30957/ijot1 t1.v5i1.636.

Writing is an activity to deliver messages such as ideas, feelings and information in writing to others. As a form of verbal communication, writing involves the element of the writer as the conveyor of the message, message or content of the writing, the writing channel and the reader as the recipient of the message (Thompson, 2013; Harmer, 2008). As a language skill writing is a complex activity, the writer compiles and organizes the contents of his writing and pouring in the formulation of various written languages and other writing conventions as a means of indirect communication (Dykstra, n.d.; Tarigan, 2008:3). Writing is better given to Junior High School students (SMP) at the final level. However, simple writing skills can be given to students since grade VII.

Therefore, writing skills should be emphasized since basic education, namely when the child is in elementary school. The development and improvement of writing skills are carried out in elementary schools as the first experience. Writing activities make students active in learning activities, so writing skills must be true (Celce-Murcia et al., 2014).

Writing a procedure text aims to make students understand how to do something with detailed steps in sequence. The students can play a direct role in the learning process, teachers as designers, motivators, and observers. On the other hand, the students are encouraged to give individual responses. The cause of student learning difficulties comes from within the students themselves and also from outside themselves, for instance, how to present the subject matter or the atmosphere of the learning process. In this case, one of the difficulties of learning from outside the students is that the forms and models of learning presented by the teacher are less pleasant (Brown, 2018).

MTs Negeri 1 Jepara (henceforth, MTJ) is one of the national standard schools in Jepara Regency, Central Java, Indonesia. Geographically, this school is very supportive of learning. Located in the middle of the city, this school is comfortable and safe for studying and away from traffic noise.

Based on the results of observations, the researcher found that there are still some students of grade IXA of MTJ who have not yet completed the material for writing procedure texts for English lessons. The lack of students' ability in writing procedural texts was found, namely when the teacher explains that the students do not understand and cannot understand the teacher's explanation. The teachers' instruction was not clear so the students do not pay attention and listen to the teacher well. Even though, they are already good at writing, this is not the case when writing procedural texts, because students have difficulty in choosing vocabulary for the preparation of procedural texts and unsupportive media so that the students were not able to grasp what the teacher instructed to them. In addition, students' interest in writing and guidance from teachers and families is still lacking. The researcher found that when the learning took place with the procedural text material the teacher only asked the students to open the handbook, and then the students answered the questions. The teacher did not explain the procedure text clearly in advance so that students did not have idea to do the instruction. 
IJOTL TL, Vol. 5, No. 3, September 2020

p ISSN: 2502 2326; e ISSN: 2502 8278

Https://soloclcs.org; Email: ijolt1@gmail.com

Center of Language and Cultural Studies, Surakarta, Indonesia

Nuning. (2020). Picture Word Inductive Model to Improve the Ability

of Procedure Writing of the MTs Students.

IJOTL TL (2020), 5(3), 181 196. DOI: 10.30957/ijot1 t1.v5i1.636.

To overcome these student problems, the researcher tried to apply the strategy Picture Word Inductive Model (PWIM) to help students find as much vocabulary as possible to then arrange them into phrases, sentences, paragraphs and very simple short text in the form of procedures for interacting with the immediate environment. This research is interesting to do because the researcher assumes that students will be able to write a lot of vocabulary together using this strategy.

This research aims to improve the students' learning outcomes of grade IX A of MTJ in learning to write short functional text, text structure, and linguistic elements of spoken expressions. In Addition, the students learn to write procedural texts by giving and asking for short and simple information related to food/beverage recipes and manuals based on the context of their use by PWIM. With the increase in student learning outcomes, it is expected that students' writing results will be better.

\section{LITERATURE REVIEW}

\subsection{English Learning and Its Objectives}

The scope of English subjects at SMP/MTs comprises of: (a) Discourse skills, namely the ability to understand and/or produce spoken and/or written texts which are realized in four language skills, namely listening, speaking, reading and writing in an integrated manner to achieve informational literacy levels; (b) The ability to understand and create various short functional texts and monologues as well as essays in the form of procedures, descriptive, recount, narrative reports, news items, analytical exposition, hortatory exposition, spoof, explanation, discussion, review, public speaking. The gradation of teaching materials appears in the use of vocabulary, grammar, and rhetorical steps; (c) The supporting competencies, namely linguistic competence (using grammar and vocabulary, sound system, writing), sociocultural competence (using language expressions and acts in an acceptable manner in various communication contexts), strategic competence (overcoming problems that arise in the communication process in various ways to keep communication going), and discourse shaping competences (using discourse shaping tools) (Depdiknas, 2003).

English subject at SMP aims that students have the abilities of: a) Developing competence in communicating in oral and written form to achieve informational literacy levels, (b) Having awareness of the nature and importance of English to increase the nation's competitiveness in a global society, (c) Developing students' understanding of the relationship between language and culture (Depdiknas, 2003).

\subsection{Writing Skills}

Writing skill is one type of language skill that the students should master. Many experts have formulated the concept of writing (Flowerdew, 2012) defines writing skill is the ability to express ideas, opinions and feelings to other parties through written language. The accuracy of expressing ideas must be supported by the accuracy of the language used, vocabulary and grammatical and spelling usage. Gifford \& Huff (1979) explain that writing skill is a skill to express thoughts, ideas, and opinions about 
IJOTL TL, Vol. 5, No. 3, September 2020

p ISSN: 2502 2326; e ISSN: 2502 8278

Https://soloclcs.org; Email: ijolt1@gmail.com

Center of Language and Cultural Studies, Surakarta, Indonesia

Nuning. (2020). Picture Word Inductive Model to Improve the Ability

of Procedure Writing of the MTs Students.

IJOTL TL (2020), 5(3), 181 196. DOI: 10.30957/ijotl fl.v5i1.636.

something, a response to a statement of desire, or express feelings using written language.

Writing is an activity to express ideas through language media. Writing is a productive and expressive activity so that the writer must have the ability to use vocabulary, writing grammar, and language structure. Writing skill is the act of transferring thoughts and feelings into written language using symbols. In line with this opinion, Celce-Murcia et al. (2014) has different opinion that writing skill is defined as the ability to use language to express ideas, thoughts or feelings to others by using written language. Writing is an activity to express ideas, ideas, thoughts or feelings into language symbols. Meanwhile, Akturk \& Gulsecen (2017) explains that writing is an activity to convey messages (communication) using written language as a medium or tool. In written communication there are at least four elements involved, namely (1) the author as the messenger, (2) the content of the text or message, (3) the channel or media in the form of writing and (4) the reader as the message receiver. Tarigan (2008:3) has different concept that writing skill is a productive and expressive language skill that is used to communicate indirectly and not face-to-face with other parties. Meanwhile, according to Bateman (1981:77) the skill of writing essays or composing is to put thoughts into written language through sentences that are arranged completely and clearly so that they can be communicated to readers successfully. At last, Gie (2002:3) explains that writing skill is skill in making letters, numbers, names, a sign in any language with a writing tool on a certain page. Meanwhile, writing is the entire series of activities of a person expressing ideas and conveying them through written language to the reading community to be understood.

Based on some of the opinions above, it can be argued that writing skills are the skills to express ideas, ideas, feelings in the form of written language so that other people who read can understand the contents of the writing well.

\subsection{The Objectives of Writing}

Every writer should have clear purpose to write something. Suriamiharja (2007:10) states that the purpose of writing is to make what we write readable and understandable correctly by the readers having the same understanding of the language used. Meanwhile, Suparno (2002:37) explains that the objectives to be achieved by a writer are as follows:

1) Leading the reader think and reason.

2) Making the readers know about what is being reported.

3) Making the reader opinionated.

4) Making the reader understand.

5) Making the reader satisfied with the content of the essay.

6) Making the readers happy by living the values expressed such as truth values, religious values, educational values, social values, moral values, human values and aesthetic values. 
IJOTL TL, Vol. 5, No. 3, September 2020

p ISSN: 2502 2326; e ISSN: 2502 8278

Https://soloclcs.org; Email: ijolt1@gmail.com

Center of Language and Cultural Studies, Surakarta, Indonesia

Nuning. (2020). Picture Word Inductive Model to Improve the Ability

of Procedure Writing of the MTs Students.

IJOTL TL (2020), 5(3), 181 196. DOI: 10.30957/ijot1 tl.v5i1.636.

Based on the above opinions, the conclusion can be drown. The purpose of writing is so that readers know, understand and understand the 12 values in writing so that readers can think, argue or do something related to the content of the writing.

\subsection{Procedure Text}

Procedure Text is a genre of an article that shows how to make something or how to do something with sequential or step by step. The purpose of the procedure text is to provide instructions on how to do something through coherent actions or steps. In everyday life we must have made something like cooking, or done something. Sometimes we don't know how to make or do it, and then we will need a coherent process or what we usually call a procedure. So, for that, let's just look at the following explanation of the procedure text (Depdiknas, 2003).

\subsubsection{Generic Structure of Procedure Text}

Procedure text has three generic parts, namely:

1) Aim / Goal

Aim is the purpose of the Procedure text. Usually in the form of a title or description of what will be made or done.

2) Materials

This section contains a list of materials and tools for completing the procedure text. However, not all procedure text requires material. There are three types of Procedure Text that do not use materials or tools, namely:

a) Procedure Text that explains how to do instructions manually or how something can work. For example: How to use the television, the fridge, the phone, or the rice cooker, and others.

b) Procedure Text which explains the rules of how to carry out certain activities. For example: flight safety rules, video game rules, and others.

c) Procedure text that teaches people about life or is related to human nature and habits. For example: How to be happy, How to be useful for someone, how to get a boyfriend, and so on.

3) Steps

The steps section contains a series of steps to take in a sequence. These steps must be taken so that the objectives stated in the Aim / Goal section can be achieved.

\subsubsection{Characteristics of Procedure Text}

1) Using imperative sentence patterns. For example "Cut the banana into pieces", "Don't mix the coconut milk with water", "Heat the water for 5 minutes", etc.

2) Using action verbs, such as crack, chop, cut, heat, mix, and so on.

3) Using sequence adverbs such as first, second, next, then, finally, while

4) Using adverbs (adverbs) to state the details of time and place for example for "Cook the mixture for one hours", "Boil the water for 15 minutes", "Crack the egg into the bowl", and so on.

5) Using the simple present tense (Depdiknas, 2010). 
IJOTL TL, Vol. 5, No. 3, September 2020

p ISSN: 2502 2326; e ISSN: 2502 8278

Https://soloclcs.org; Email: ijolt1@gmail.com

Center of Language and Cultural Studies, Surakarta, Indonesia

Nuning. (2020). Picture Word Inductive Model to Improve the Ability

of Procedure Writing of the MTs Students.

IJOTL TL (2020), 5(3), 181 196. DOI: 10.30957/ijot1 t1.v5i1.636.

Example: Procedure Text "How to Make Mango Juice"

Ingredients: 2 ripe mangoes, 1 cup of water, 2 tablespoons sugar, a few ice cubes

\section{Steps}

1) Wash the mangoes to remove any dirt. Then peel the ripe mangoes (Wash the mango to remove dirt. Then peel the mango)

2) Cut the peeled mangoes into small pieces. (Cut the peeled mango into small parts)

3) Put them in a blender together with crushed ice, water, and sugar (put in the blender together with crushed ice)

4) Blend until smooth. (Blend until smooth)

5) Run the blended mixture through a sieve. (Filter the blended mangoes through the sieve)

6) Throw away the leftover pulp and mango fibers. (Remove fiber and mango dirt)

7) Serve the juice in glasses with a piece of mango attached to the side for garnish. (Serve juice in a glass with mango chunks at the end of the glass as a garnish).

\subsubsection{Picture Word Inductive Model}

PWIM was developed using photos containing objects that are familiar for the students to produce words from children. This model helps students discover some of the vocabulary through what they read and see, as well as the vocabulary they write, and also discover the phonetic and structural principles that are present in words.

The purpose of using PWIM is to develop vocabulary, concepts about words, sentences and paragraph structure. The strength of using this strategy is that it helps build vocabulary and writing skills. The following is a list of advantages of using PWIM (Joyce \& Weil, 2009).

1) This strategy emphasizes phonics, grammar, mechanics, and the use of Standard English.

2) The pictures provide a tangible reference for learning new words, phrases and sentences.

3) The students feel part of the classroom community and can learn successfully in class activities as they use images related to the content material under study,

4) The picture word graph serves as a direct reference to allow students to add words to their visual vocabulary.

5) The students are assisted in seeing patterns and relationships in English, enabling them to apply learning to words they have just encountered.

6) The students hear and see correctly spelled words and successfully learn in correct spelling and writing.

7) The students benefit from teacher modeling from the key words and concepts being demonstrated.

This strategy can be used with the whole class, small groups, in pairs, or individually to lead students to ask questions about words and add them to their vocabulary, discover phonetic and structural principles, and engage in reading and 
IJOTL TL, Vol. 5, No. 3, September 2020

p ISSN: 2502 2326; e ISSN: 2502 8278

Https://soloclcs.org; Email: ijolt1@gmail.com

Center of Language and Cultural Studies, Surakarta, Indonesia

Nuning. (2020). Picture Word Inductive Model to Improve the Ability

of Procedure Writing of the MTs Students.

IJOTL $\sim T$ (2020), 5(3), 181 196. DOI: 10.30957/ijotl t1.v5i1.636.

writing activities. While some skills can be taught explicitly, PWIM is designed to harness students' ability to think inductively (Herlinawati \& Hidayati, 2014).

The learning process begins by asking students to write down as many nouns as they can from the picture they see. For example, the focus on the image is Instant Noodles or Television. Students can write a few words whether they appear in the photo/picture or not. Students can write down the steps to make or use the objects in the picture. Then students are asked to sequence the steps coherently and as much as possible so as to form a procedural text properly and correctly (Novia, 2015). The hypothesis of this research is proposed as follows: "The Learning to write in English using PWIM can improve student learning outcomes of students of MTJ".

\section{METHODS}

The design of this study is action research (Arikunto, Suhardjono \& Supardi, 2006; Fueyo \& Koorland, 2007). The research subjects were 27 graders of MTJ, consisting of 7 male students and 20 female students, aged averaging between 14 and 15 years. The results of observations of student activities during learning, both-task and off-task, are primary data. The secondary data was interview with several representatives the students.

This research was conducted for 3 cycles. During the entire cycle, the students work in groups of four. In first cycle the students describe a picture of a certain food or drink menu using the PWIM method (Rust \& Clark, 2007; Herlinawati \& Hidayati, 2014), while in second cycle the students explain the procedure for making food/drink recipes with procedures such as in cycle 1 . In third cycle, the students ask for or give information on food/beverage recipes using the strategy PWIM. The data collection was carried out simultaneously with observation during the action, while data analysis was carried out simultaneously at the time of reflection on the action (Klein, 2012). From the analysis/reflection results, it can be seen whether the action will be stopped (if it has reached the target) or continue to achieve the target.

\section{RESULTS}

\subsection{The Description of Initial Conditions}

Data on the information regarding food/drink recipes were in the form of several phrases. The data show that it is a good start if students are able to compose a few phrases correctly. The students can respond to teacher questions but only in the form of one or two words. When the teacher asked to make a phrase, only 7 students responded. For this reason, it is necessary to conduct research to solve the problems faced by the students of MTJ.

Some various factors influence why the above condition happens. But the most important factor is the lack of vocabulary the students get. Although the written language errors are not immediately recognized by others, written language is more complex, complete and formal.

\subsection{The Action results}


IJOTL TL, Vol. 5, No. 3, September 2020

p ISSN: 2502 2326; e ISSN: 2502 8278

Https://soloclcs.org; Email: ijolt1@gmail.com

Center of Language and Cultural Studies, Surakarta, Indonesia

Nuning. (2020). Picture Word Inductive Model to Improve the Ability

of Procedure Writing of the MTs Students.

IJOTL TL (2020), 5(3), 181 196. DOI: 10.30957/ijot1 t1.v5i1.636.

This action study was carried out in 3 cycles, and each cycle consisted of 4 stages. Actions are carried out by different methods. This is intended to determine the extent to which the use of the strategy PWIM can improve the writing of procedure genre of MTJ students. As previously stated, the first cycle of action, the students describe certain objects in groups of 4 then individually using the PWIM model. In second action, as the same before, only the object is an image of a certain food or drink. While in the third action, the students gave and asked for information related to food recipes based on group 4 pictures without procedures as in the PWIM. Let us see the Implementation, Observation and Reflection of each cycle.

\subsubsection{Cycle I \\ Acting}

Acting is carried out in 4 stages, such as in daily learning, namely Building Knowledge of the Text (BkoF), Modeling of the Text (MoT), Joint Construction of the Text (JCoT), and Independent Construction of the Text (IcoT). However, observations are only focused on when the students take part in the Joint Construction of the Text (JCoT) and Independent Construction of the Text (IcoT) stages. At JcoT stage, the students work together to compile a procedure text about a certain recipe with stages as in the model.

\section{Observing}

From the results of observing the actions in cycle I, it revealed that not many students could make the steps to make food/drink recipes correctly. There are still many students who do undesirable activities during the lesson such as chatting, looking at pictures, writing in Indonesian, and even laughing out loud after seeing pictures.

Even so, in this cycle there has been an increase in student learning outcomes in learning to write in English, but it has not met the predetermined success criteria, namely $75 \%$ of all students achieve minimum passing grade (KKM) 75. Only 10 students $( \pm 37.04 \%)$ managed to achieve KKM grade.

\section{Reflecting}

When the reflection is carried out, the students stated that they still have difficulty to write the sentences of giving and asking for information related to food recipes. The teacher reiterates that what the students have to do first is mention the objects seen in the picture then try to make the steps to make them coherent. The students do not need to be stuck having to write many sentences other than those related to pictures.

The teachers still have not provided much assistance to the students in this cycle. The teacher is still busy observing students. The action in the second cycle was planned from these results.

\subsubsection{Cycle II.}

Acting 
As in the cycle one, the actions in this cycle are also carried out in 4 stages, such as in daily learning, namely BkoF, MoT, JCoT, and IcoT.

In second cycle of action, the students still work in groups of four and then independently make steps to make food recipes. Lessons begin by reviewing images of specific objects using procedures such as the PWIM model. Then students are asked to practice doing it in front of the class.

The students work in groups of four at the JCoT stage. At this stage they write down some steps to make food/drinks that are in the picture or that are related to the picture but not in the picture. Then they tried to write coherently, starting from mentioning the ingredients, continuing to make the steps for it to become a good and correct procedural text.

\section{Observing}

In this cycle, the writing strategy does not change. The students continue to work in groups of four and get pictures of specific people to describe with the PWIM model. During the learning process, almost more than $50 \%$ of students learn successfully. They were not interested in joining this activity. There were 17 students $( \pm$ $62.96 \%$ ) succeeded in active learning. There are still students who are less successful in learning. Students contribute to each other about words that can be used to make steps to make food/drink recipes.

The teacher provides more feedback to students so that they can come up with as much vocabulary as possible based on the pictures. Students are invited to directly write down the words based on the pictures or discuss them first with their friends in the group.

\section{Reflecting}

Based on the reflection of learning carried out based on the activity, it was found that students enjoyed the activity more by sharing the vocabulary they came up with to make procedural texts in the form of steps to make food recipes.

To help generate new vocabulary from the students, the teacher provides elicitation feedback. To ascertain whether the increase the students' learning outcomes to write English text was due to the use of PWI, action was taken in the third cycle.

\subsubsection{Cycle III. Acting}

Like the previous two cycles, the actions in this cycle are also carried out in four stages, namely BkoF, MoT, JCoT, and IcoT. Here's the explanation.

(1) $\mathrm{BkoF}$

- The teacher reviews how to make food/drink recipes as in the previous meeting.

- The teacher shows a picture of a certain place

- The teacher asks several questions that can provoke students to say a few words about the picture. 


\section{(2) MoT}

With the knowledge of how to describe certain objects at the previous meeting, students are invited to make steps to make food recipes without going through procedures such as in PWIM.

(3) JcoT

- The students are divided into groups of four.

- Each group is given a different picture of a certain place.

- The students are asked to provide recipes for how to make food / drinks in groups of four in the same way as in the Modeling of the text example / stage, namely directly giving and asking for information related to food / drink recipes based on pictures without going through the PWIM procedure.

- The teacher observes the student's work while noting important things and providing explanations.

(4) IcoT

- The teacher displays a picture of a certain place.

- The students are asked to describe the pictures individually.

\section{Observing}

Based on observations during the action in the third cycle, it was obtained data that student learning outcomes in learning decreased. A total of 27 students $100 \%$ ) managed to write down the procedure for making certain food recipes correctly and coherently.

\section{Reflecting}

Based on the results of reflection, it was found that the students' outcomes in learning to write English Basic Competencies of comparing social functions, text structure, and linguistic elements. The oral and written procedural texts are giving and asking for information related to food recipes and manuals, short and simple, in accordance with the context of its use because the strategy is not used PWIM even though students still have pictures.

\section{DISCUSSION}

At the first meeting, the difficulties have been found by the researcher on applying writing text to the students of IX A. Then the researcher tried to choose PWIM method to make the students able to write procedure text. Before applying the cycle, the researcher found only about $17 \%$ was able to give simply description of procedure text. Then the researcher try to apply PWIM to the students, They are; Building Knowledge of the Text (BkoF), Modeling of the Text (MoT), Joint Construction of the Text (JCoT), dan Independent Consrtuction of the Text (IcoT). But the research focused only for 
IJOTL TL, Vol. 5, No. 3, September 2020

p ISSN: 2502 2326; e ISSN: 2502 8278

Https://soloclcs.org; Email: ijolt1@gmail.com

Center of Language and Cultural Studies, Surakarta, Indonesia

Nuning. (2020). Picture Word Inductive Model to Improve the Ability

of Procedure Writing of the MTs Students.

IJOTL TL (2020), 5(3), 181 196. DOI: 10.30957/ijot1 t1.v5i1.636.

students who joined Joint Construction of the Text (JCoT), dan Independent Consrtuction of the Text (IcoT).

Table 1 the results of daily tests on cycle 1

\begin{tabular}{clc}
\hline No & \multicolumn{1}{c}{ Explanation } & $\begin{array}{c}\text { Daily Test of } \\
\text { Cycle } 1\end{array}$ \\
\hline 1 & Average & 62 \\
\hline 2 & The highest value & 83 \\
\hline 3 & The Lowest value & 30 \\
\hline 4 & Number of Students & 28 \\
\hline 5 & $\begin{array}{l}\text { Students who have not yet } \\
\text { completed }\end{array}$ & 1 \\
\hline 6 & Students who have completed & 27 \\
\hline 7 & Percentage of completeness & 37 \\
\hline
\end{tabular}

The chart of the results of daily tests of cycle 1 can be seen in chart 1 below:

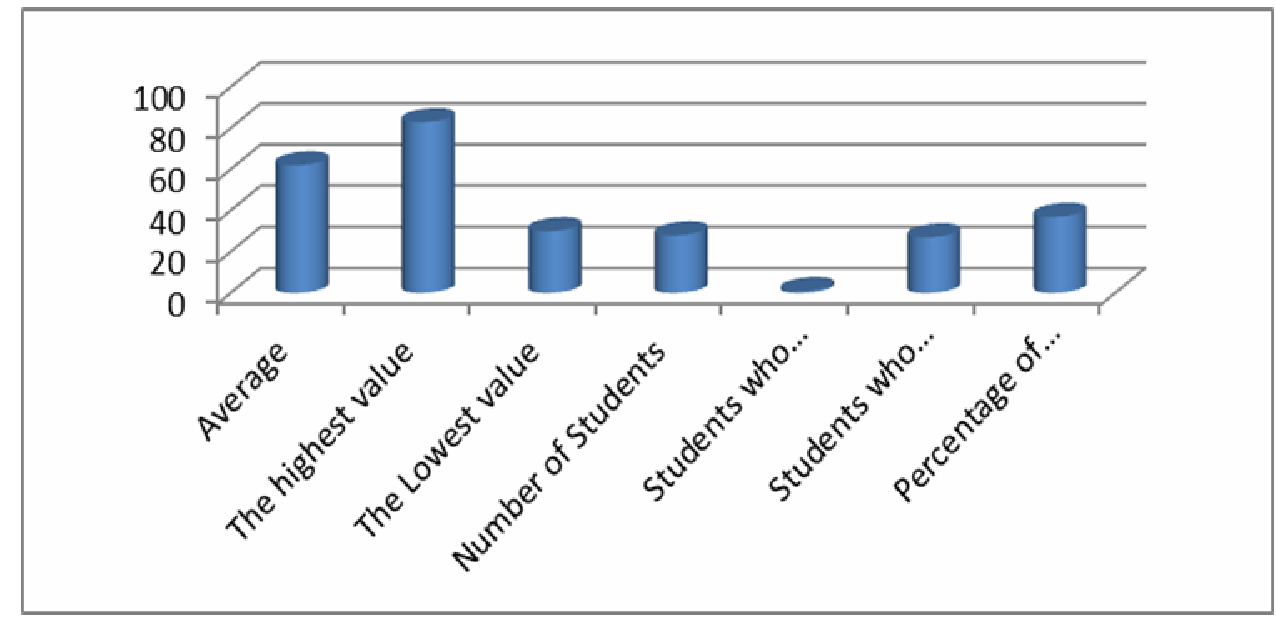

On second cycle, the researcher found that more than $50 \%$ students started to be able to compile the procedure text by the helping of PWIM. The researcher make a group of discussion to make the students could make steps on composing procedure text; the researcher gave feedback to make the students having more understanding of creating procedure text. The following is the data on cycle 2 
IJOTL TL, Vol. 5, No. 3, September 2020

p ISSN: 2502 2326; e ISSN: 2502 8278

Https://soloclcs.org; Email: ijolt1@gmail.com

Center of Language and Cultural Studies, Surakarta, Indonesia

Nuning. (2020). Picture Word Inductive Model to Improve the Ability

of Procedure Writing of the MTs Students.

IJOTL TL (2020), 5(3), 181 196. DOI: 10.30957/ijotl tl.v5i1.636.

Table 2 the results of daily tests on cycle 2

\begin{tabular}{llc}
\hline No & \multicolumn{1}{c}{ Explanation } & $\begin{array}{c}\text { Daily Test of } \\
\text { Cycle 2 }\end{array}$ \\
\hline 1 & Average & 76 \\
\hline 2 & The highest value & 86 \\
\hline 3 & The Lowest value & 65 \\
\hline 4 & Number of Students & 28 \\
\hline 5 & $\begin{array}{l}\text { Students who have not yet } \\
\text { completed }\end{array}$ & 0 \\
\hline 6 & Students who have completed & 28 \\
\hline 7 & Percentage of completeness & 62 \\
\hline
\end{tabular}

The chart of the results of daily tests of cycle 2 can be seen in chart 2 below:

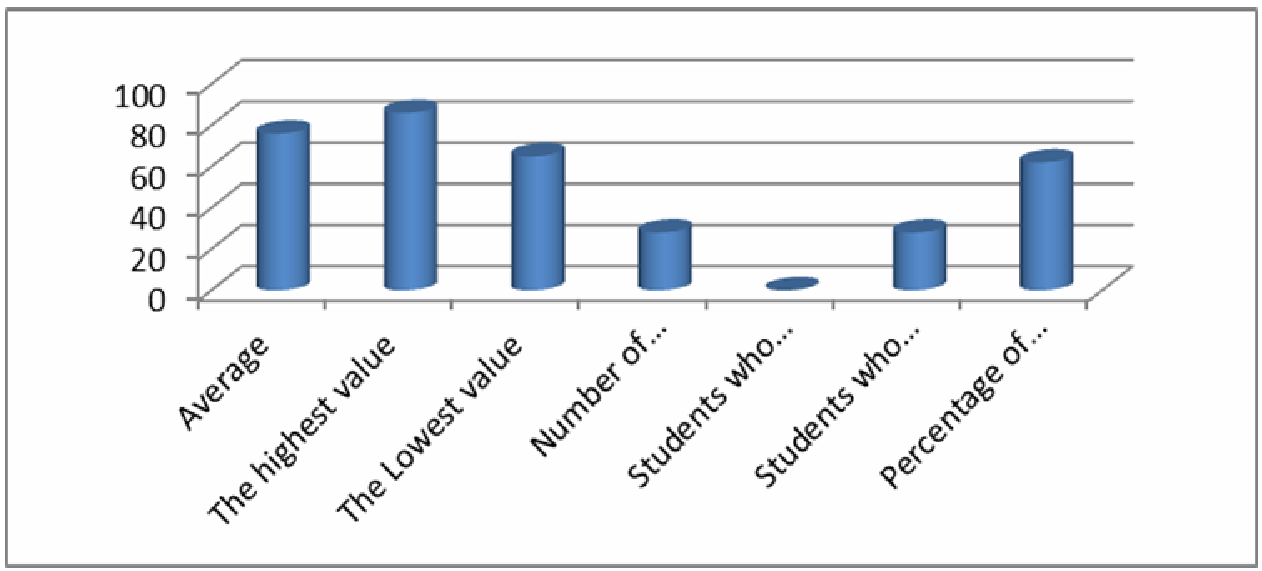

On the third cycle, a great progress reached by the researcher. It's found that all students are able to create procedure text correctly after applying three cycles. Stepping forward using PWIM to support the students on improving writing skill especially on writing procedure text, the following is the result on cycle 3

Table 3 the results of daily tests

\begin{tabular}{clc}
\hline No & \multicolumn{1}{c}{ Explanation } & $\begin{array}{c}\text { Daily Test of } \\
\text { Cycle } 3\end{array}$ \\
\hline 1 & Average & 80 \\
\hline 2 & The highest value & 88 \\
\hline 3 & The Lowest value & 75 \\
\hline 4 & Number of Students & 28 \\
\hline 5 & $\begin{array}{l}\text { Students who have not yet } \\
\text { completed }\end{array}$ & 0 \\
\hline
\end{tabular}


IJOTL TL, Vol. 5, No. 3, September 2020

p ISSN: 2502 2326; e ISSN: 2502 8278

Https://soloclcs.org; Email: ijolt1@gmail.com

Center of Language and Cultural Studies, Surakarta, Indonesia

Nuning. (2020). Picture Word Inductive Model to Improve the Ability

of Procedure Writing of the MTs Students.

IJOTL TL (2020), 5(3), 181 196. DOI: 10.30957/ijotl tl.v5i1.636.

\begin{tabular}{clc}
\hline 6 & Students who have completed & 28 \\
\hline 7 & Percentage of completeness & 100 \\
\hline
\end{tabular}

The chart of the results of daily tests of cycle 3 can be seen in chart 3 below:

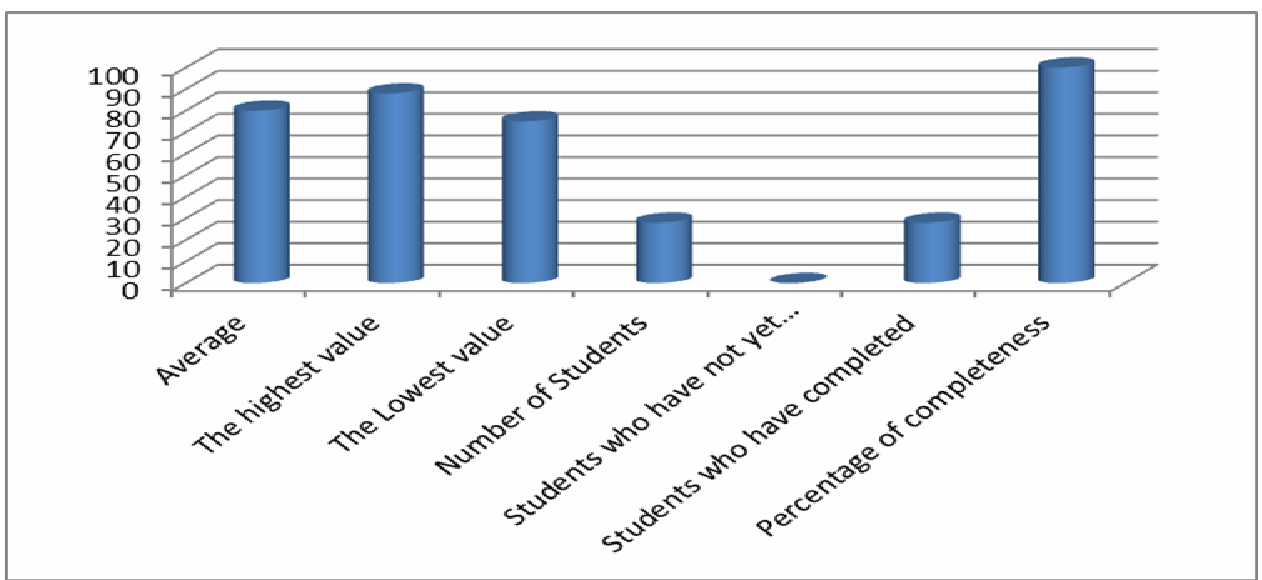

The circumstances proof that on teaching we can use some methods to make the students able to understand our materials. In this case, the writer uses PWIM on creating procedure text. It is no matter how the students or kids mostly like to see coloring picture because it will enlarge their interest and help them to create the text. They also can compile the steps by seeing the pictures. In fact, only $17 \%$ students knew about procedure after they got explanation from the researcher. Then, the use of PWIM can help them increasing result on their ability to create procedure text, it become $36 \%$ for the first cycle. The second cycle shows that about $62 \%$ students are able to write procedure text. The third cycle shows that all students are able to write a procedure text. The research shows that we got lots of benefit on using PWIM, its proven that this method is effective.

The results of the implementation of the action cycle I to cycle III proves that the use of PWIM in learning to write English texts can improve the students' ability to write procedure texts by MTJ students on the topic "describing certain objects". Overall, the increase in student learning outcomes can be seen in the following graph.

Chart 4 The Minimal Grade achievements (KKM) of the students in grade IX A in making procedural texts before and after the three-cycle action 


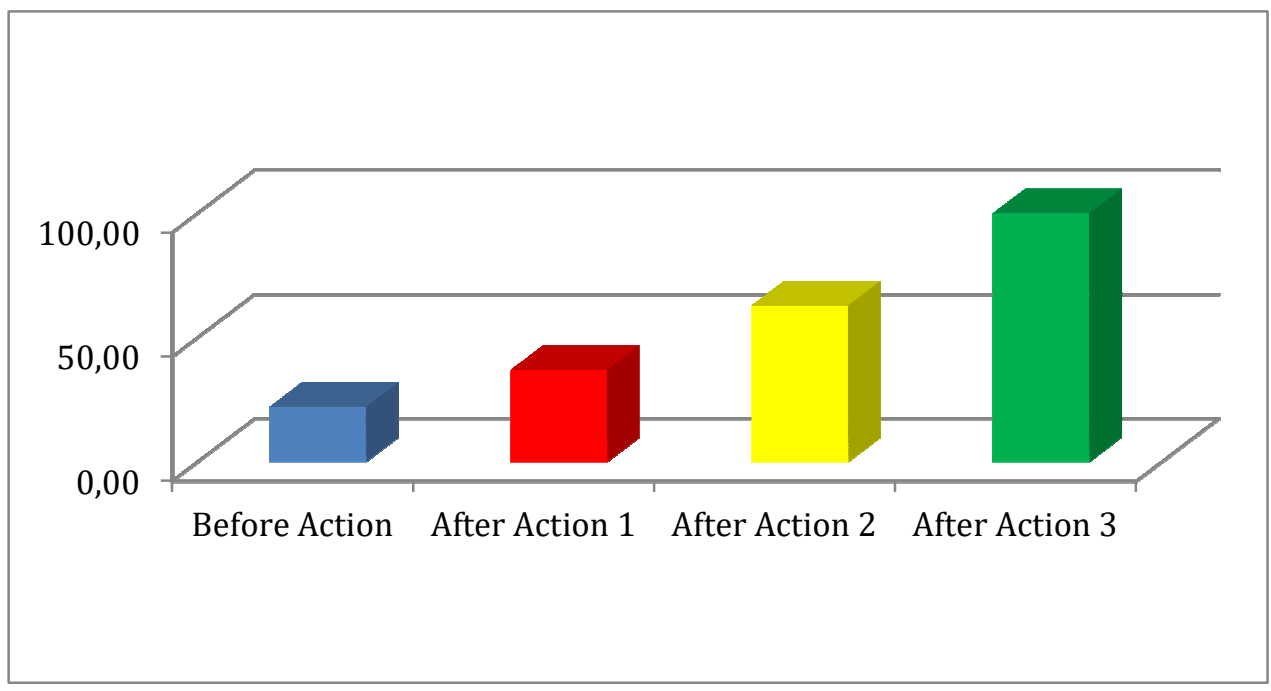

PWIM has proven to be successful in helping students of MTJ to improve their learning outcomes in learning to write in English, especially in giving or asking for information on food/drink recipes. The initial condition before the action was held, only 8 students $(22.22 \%)$ could describe certain objects in English. After the first cycle of action, there was an increase in the number of students who succeeded in learning. 10 students $(37.04 \%)$ succeeded in learning in the activity referred to. In the second cycle, the number increased to 17 students $(62.96 \%)$, and in the third cycle there were 27 students $(100 \%)$ who succeeded in learning.

\section{CONCLUSION}

The results of this study reveals that the writing ability of text procedure of the MTJ students improved after students received PWIM though the classroom action research. Before the action, only 6 students could provide and ask for information regarding food/drink recipes in English. When the interview was held, the answers to the reasons why students were not able to participate in learning to write in English were obtained, including: a. students do not have what material to write, and b. students are bored with techniques that seem monotonous.

After 3 cycles of action were held, there was an increase on the students' learning outcomes in giving and asking for information related to food recipes. In first cycle, the students were asked to write a procedural text about food in the picture in a group of four using the strategy PWIM. As a result, only 10 students $(37.04 \%)$ could make the procedure text correctly. There are still many students who have not been able to do it properly, and tend to do undesirable activities. In second cycle, the students were asked to compile a procedural text using the strategy PWIM. There were 17 students $(62.96 \%)$ who succeeded in making the procedure text correctly. The results have reached the expected target. But to find out whether PWIM helped this increase, action was continued. In third cycle, the students were asked to write a procedural text 
IJOTL TL, Vol. 5, No. 3, September 2020

p ISSN: 2502 2326; e ISSN: 2502 8278

Https://soloclcs.org; Email: ijolt1@gmail.com

Center of Language and Cultural Studies, Surakarta, Indonesia

Nuning. (2020). Picture Word Inductive Model to Improve the Ability

of Procedure Writing of the MTs Students.

IJOTL TL (2020), 5(3), 181 196. DOI: 10.30957/ijot1 tl.v5i1.636.

about food recipes using the strategy PWIM. As a result, only 27 students (100\%) succeeded in active learning.

The advantage of using PWIM is that the students become more enthusiastic in participating the learning to write English texts because they are assisted in bringing up the vocabulary they will use. In addition, the contribution of students in bringing up vocabulary makes students more challenged. Meanwhile, the drawback of using PWIM is that this method can only improve the writing ability because each student experiences different problems and has different ways of learning.

This study suggest that that the teachers try to apply this method for their class to find out whether the PWIM can really help class XI students write procedural texts coherently and correctly. In addition, teachers should develop classroom action research on other aspects with different methods so that any deficiencies during the teaching and learning process can be identified as obstacles.

\section{REFERENCES}

Akturk, C., \& Gulsecen, S. (2017). Foreign Language Education and E-Learning. EJournal of UDEEWANA, 3(1), 40-50.

Arikunto, S., Suhardjono, \& Supardi. (2006). Penelitian Tindakan Kelas. Jakarta: PT Bumi Aksara.

Bateman, B. (1981). Reviews: The Cambridge Guide to Second Language Teacher Education. The Modern Language Journal, 65(2), 203-240. https://doi.org/10.1111/j.1540-4781.1981.tb00975.x

Brown, H. D. (2018). Language Assessment: Principles and Classroom Practices. In Pearson Education, Inc. (1 st ed.). Longman. www.longman.com

Celce-Murcia, M., Brinton, D., \& Snow, M. A. (2014). Teaching English as a second or foreign language (p. 706).

Depdiknas. (2003). Standar Kompetensi Mata Pelajaran Bahasa Inggris Sekolah

Menengah Pertama dan Madrasah Tsanawiyah. Jakarta: Direktorat Pendidkan

Dasar dan Menengah.

Depdiknas. (2010). Pedoman Penulisan. Buku Bahasa Inggris SMP/SMA. Naskah pada

Pusat Perbukuan. Jakarta: Pusat Perbukuan Depdiknas.

Dykstra, G. (n.d.). Eliciting Language Practice in Writing -.

Ferrance, E. (2000). Action Research (1st ed.). Brown University.

Flowerdew, J. (2012). English for Research Publication Purposes. In The Handbook of English for Specific Purposes (pp. 301-321).

https://doi.org/10.1002/9781118339855.ch16

Fueyo, V., \& Koorland, M. A. (2007). Teacher as researcher: A synonym for professionalism. Journal of Teacher Education, 48(5), 336-338.

Gie, T. L. (2002). Terampil Mengarang. Yogyakarta: Balai Pustaka. 
IJOTL TL, Vol. 5, No. 3, September 2020

p ISSN: 2502 2326; e ISSN: 2502 8278

Https://soloclcs.org; Email: ijolt1@gmail.com

Center of Language and Cultural Studies, Surakarta, Indonesia

Nuning. (2020). Picture Word Inductive Model to Improve the Ability

of Procedure Writing of the MTs Students.

IJOTL TL (2020), 5(3), 181 196. DOI: 10.30957/ijotl tl.v5i1.636.

Gifford, C., \& Huff, J. (1979). Using an Isntructional Management System to Teach

Writing Skills. NASSP Bulletin, 1, 1-476.

https://doi.org/10.1017/CBO9781107415324.004

Hammond, J. e. (2012). English for Social Purposes: a Handbook for teachers of Adult

Literacy. Sydney: NCELTER.

Harmer, J. (2008). How to Teach English. London: Longman.

Herlinawati, \& Hidayati. (2014). Picture Inductive Word Model (PWIM): Improving

Students' Ability in Writing a Descriptive Paragraph. ELT-Lectura, 1(2), 9-14.

https://doi.org/10.31849/elt-lectura.v1i2.452

Joyce, B., \& Weil, M. (2009). Models of Teaching, Second Edition. New Jersey:

Prentice Hall Inc.

Klein, S. R. (2012). Action Research Methods: Plain and Simple (1st ed.). Palgrave Macmillan US.

Novia, F. (2015). Promoting Picture Word Inductive Model ( PWIM ) to Develop Students' Writing Skill. Premise Journal, 4(1).

Rust, F., \& Clark, C. (2007). How to do action research in your classroom; lessons from the teachers network leadership institute.

Suparno, Y. M. (2002). Keterampilan Dasar menulis. Jakarta: Universitas Terbuka.

Suriamiharja, A. (2007). Dasar-Dasar Keterampilan Menulis. Bandung: Angkasa.

Tarigan, H. G. (2008). Membaca Sebagai Suatu Keterampilan Berbahasa. Bandung:

Angkasa.

Thompson, P. (2013). The Handbook of English for Specific Purposes. In B. Paltridge \& S. Starfield (Eds.), The Handbook of English for Specific Purposes (1st ed.). A John Wiley \& Sons, Ltd., Publication.

https://doi.org/10.1002/9781118339855.ch15 